\title{
The fishery in the northern regions of the Far East of the USSR in the context of late Soviet modernization
}

\author{
Nonna Platonova ${ }^{1, *}$ \\ ${ }^{1}$ Far Eastern State Transport University, 47 Serysheva street, Khabarovsk, 680000, Russia
}

\begin{abstract}
The article describes the development of the fishing industry in Kamchatka, Sakhalin, and Magadan regions in 1965-1985. In a general historical context, the article pays attention to the modernization processes in the fishery of the northern regions of the Far Eastern territory, emphasizing general trends and differences in their dynamics. The special importance and level of development of the material and technical base of the fishing industry is noted. The article reveals the working conditions of ship repair enterprises and the reasons for the financial deficit of ship repair. Statistical data on the accident rate of fishing vessels of the branch administrations of Kamchatka, Sakhalin, and Magadan are analyzed. The results of the introduction of 200-mile economic zones that complicated the fishing activities of enterprises and the fleet of the fishing industry in the northern regions of the Soviet Far East are shown. It was found that social and economic experiments in the late Soviet period and modernization, which was carried out from above by the political elite, did not eliminate disproportions in the development of the fishery. Territorial remoteness, difficulties of timely material and technical supply and ship repair and maintenance problems were difficult-to-overcome challenges which accelerated the systemic crisis in the fishery.
\end{abstract}

\section{Introduction}

The Far Eastern basin occupies one of the leading positions in the development of the fishing industry and the fishery industrial cluster of the Russian Federation. The Far Eastern Basin accounts for the bulk of fish catch and fish production, which is determined by the territorial access to biological resources of the Okhotsk, Bering and Japan Seas, and the northwestern Pacific Ocean; the historically traditional nature of fishing; a significant share of labor resources. For many regions of the Far Eastern Federal District (FEFD), it acts as a town and village-forming component. In addition, the proximity of markets of the neighboring countries of the Asia-Pacific region, which have a powerful economic potential, reveals multifaceted prospects for international cooperation, influences the government strategy for the development of the FEFD fishery industry. The historical retrospective of the results of late Soviet modernization of the fishing industry of Sakhalin, Kamchatka, and Magadan regions is of scientific interest.

\section{Historiography, problem and purpose}

In Soviet historiography, the history of the fishing industry of the Far Eastern territory was represented by articles [1], but the studies by A.T. Mandrika, which were published in the Soviet and modern periods, are of special interest. Analytical assessments and conclusions of this author reveal the regional specifics of the fishing industry, show its influence on the national economy of the Far Eastern territories [2].

At the latest stage, many problems of the history of the development of the Far Eastern region were rethought. The research on the socio-economic development of the fishing industry, its material, technical and personnel support has become actualized, which is reflected in the works by Far Eastern authors [3-5].

However, there are no special studies that describe the state of the fishing industry in the northern regions of the Far East in the late Soviet period at the latest stage.

The subject of the article is the development of the fishing industry in the northern regions of the Far East in the context of late Soviet modernization (1965 - 1985).

The purpose is to study the development of the fishing industry in the northern regions of the Far East through the analysis of archival and statistical data, factors and methods that determined the dynamics of the industry in the context of the late Soviet modernization.

Research methods: problem-chronological, statistical analysis, and comparative.

\section{Results and discussion}

In the economy of the Soviet Far East, the fishing industry, being the basic sector, played an important role in the food supply of the country. The Far Eastern fishery basin supplied more than $1 / 3$ of the all-Union catch of fish and sea animals. Sectoral enterprises produced 6.1 and 15.9 million cans of crab and salmon; $41 \%$ of fish products were exported. Only Japan 
received $81 \%$ of red caviar and $56 \%$ of seafood. In particular, the fishing industry of the Sakhalin region supplied many types of finished products and raw fish to Singapore, Japan, as well as to France and Belgium, receiving various imported consumer goods, specialized machinery and equipment $[6$, F. 399. Op. 3. V. 3. D.1315. P. 2; F. 399. Op. 3. V. 3. D.1435. P. 107 - 108; F. 399. Op. 3. D.1483. P. 69 rev.].

The dynamics of the progressive development of the fishing industry was determined by the Pacific seaports in Magadan, Petropavlovsk-Kamchatsky, Kholmsk, Nevelsk, etc., which were centers for fish processing with an annual cargo turnover of about $60 \%$ An important role was played by their proximity to rich fishing areas, for example, to the ports of the Kamchatka region. Thus, the distance from the Bay of Lavrov, located in the northwestern part of the Olyutorsky Bay in the Bering Sea, to the fishing area of the Pribylov Islands was 870 miles, while from Vladivostok to the same islands 2500 miles [7].

The coastal strip of the Sea of Okhotsk (about 2.5 thousand $\mathrm{km}$ long) and the rich fish resources of the Amur river with its tributaries predetermined the specialization of a number of northern regions (Okhotsk, Tuguro-Chumikan, Nikolaev, Ulcha, Vanin and Sovetsko-Gavan) in the fishing industry [8, F.R-353. Op. 10. D. 350. P. 5].

In the second half of the $1960 \mathrm{~s}$, the fishery industry was well-coordinated under the jurisdiction of the industrial-territorial Main Directorate of Fisheries of the Far Eastern Basin "Dalryba" (Vladivostok). It included the territorial administrations "Primorrybprom", "Sakhalinrybprom", "Kamchatrybprom", "Magadansky", "Nizhneamursky", "Okhotsk" trusts, the Department of Whaling Flotillas and "Vostokrybholodflot". In May 1970 the Department "Dalmoreproduct" was created [5]. A significant contribution to the development of the fishing industry was made by the Pacific Department of Reconnaissance and Research Fleet (TURNIF) and the Pacific Research Institute of Marine Fisheries and Oceanography with offices in Kamchatka, Sakhalin, Magadan and Chukotka.

The economic reform of 1965, which initiated the modernization processes, revealed miscalculations of self-supporting experimentation, emphasizing the problems of the material, technical and personnel potential of sectoral enterprises. Heads of the territorial departments solved complex strategic tasks, which were aimed at expanding the fishing areas, developing new stocks of biological resources in the open parts of the Okhotsk and Bering Seas, and industrializing the production processes, increasing the output of fish food products. For the party elite of the USSR, it was clear that the fishing enterprises and the fishing fleet of the Sakhalin, Kamchatka, and Magadan regions were not ready for the forthcoming reorganization. In this regard, the USSR State Planning Committee developed new working conditions whoch should be implemented in January 1, 1968, but by that time only accompanying documents had been prepared and standards for working capital had been developed. In the following years, the process of curtailing economic reform began, the transformation of socio-economic stability into stagnation intensified, so since the mid-1970s, the growth rates in the fishing industry of the Far Eastern territory, although they remained high, nevertheless, the economic crisis affected them. The introduction of market elements was incomplete [6, F. 4372. Op. 66. D. 107. P. 182 - 184].

Another factor that hindered the economic reform in the fishing industry was the uneven development of regional administrations. The Dalryba Main Directorate made biased administrative decisions, thereby creating serious difficulties. In particular, the planned targets for daily fishing for the large freezer fishing trawler (BMRT) Primorrybprom were lower than for similar vessels of Kamchatrybprom by $8 \%$ in $1963,32 \%$ in $1964,34 \%$ in 1965 , and $13 \%$ in 1966.

The sectoral specificity of the remote northern regions actualized the problems of timely fuel supply for ships. However, in 1965 Primorrybprom received 35\% more fuel for the export of finished products, while the Kamchatka Administration received $32.5 \%$ less fuel. There were also unreasonable disproportions in the provision of fishing vessels with a receiving and transport fleet: while waiting for the delivery of finished products, the downtime for one BMRT of the Primorsky Department was 8 days, for Kamchatka - 22 days. Repeated failures in the provision of refrigerated vessels were the result of financial losses of the coastal fish processing enterprises of Kamchatka region. In 1966, the fish processing plant in Anapka suffered losses in the amount of 470 thousand rubles.

These "manifestations of parochial tendencies" on the part of the central administration were desscribed in a letter addressed to the department of light and food industries of the Central Committee of the CPSU by Orlov, the first secretary of Kamchatka party committee, who suggested making changes in the fisheries management system by creating the regional Main Directorate subordinate to the USSR Ministry of Fisheries. His views were supported by the first secretary of the Sakhalin regional committee P.A. Leonov.

However, these plans were not implemented, since for the top party leadership, reorganization of the fish industry seemed economically inexpedient. However, the powers of territorial production departments were expanded, the deployment of the fleet was optimized, the volumes of centralized financing increased, etc [9, F. 5. Op. 58. D. 110. P. 24, 29, 32].

The governement strategy for the accelerated comprehensive development of the Far East, which had ambiguous consequences, contributed to significant economic transformations in the fishing industry. On the one hand, trawl fishing, carried out in the coastal zones of the Tatar Strait, replaced oceanic fishing, which significantly increased the volume of fishing on Sakhalin and Kamchatka (Figure 1).

An important result was the construction of an active oceanic fishing base located in the north of the Khabarovsk Territory in the city of Sovetskaya Gavan. Capital investments in its material and technical development reached 24 million rubles. New jobs were created, which increased the influx of people to the area. 
The finished products, the annual volume of which exceeded 20 million conventional cans of canned food, were supplied to various regions of the USSR and for export. The basis of the base was the fishing fleet with special fishing vessels, where the processing of raw fish was carried out, and in the working village of Lososin there were specialized workshops for the production of finished products. Raw materials for processing were partially supplied by Vladivostok and Khabarovsk, separate fishing collective farms, tin containers came from Kholmsk and Nakhodka. In general, the opening of the active oceanic fishing base marked a new trend in the development of the fishing industry throughout the Far East of the USSR [8, F.P-137. Op. 14. D. 2254. P. 75].

However, on the other hand, this led to some degradation of coastal fisheries, which particularly affected the settlements in the fishing areas of the Lower Amur, the Amur estuary and the western coast of Kamchatka [10].

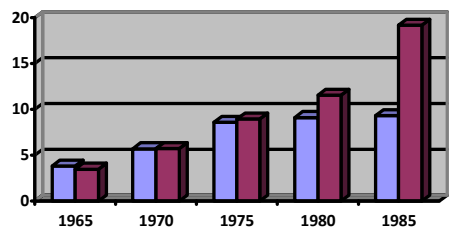

Sakhalin region 口Kamchatka region

Figure 1. Indicators of fishing on Sakhalin and Kamchatka in 1965 - 1985 (In million tons) [12, F. 17. Op. 150. D. 465. P. 7].

In the late Soviet period, the main vector of the government economic policy was focused on strengthening the material and technical base of the fishing industry; therefore, the fishing fleet was provided with new vessels. As a result, in the 1970s, Sakhalinrybprom's fleet consisted of 33 BMRTs, 47 Medium Fishing Freezer Trawlers, 80 Medium Fishing Trawlers, 40 Fishing Seiners, 70 Fishing Freezer Seiners, 8 floating bases and factories. Between 1976 and 1985, the volume of government support for the regional fishing industry amounted to 53 million rubles [11, F. 540. Op. 1. D. 728. P. 4].

"Kamchatrybprom" possessed 257 fishing and fish processing vessels which had modified equipment for the production of food products [12, F. 17. Op. 106. D. 404. P. 2]. By 1985, the fishing industry numbered 288 vessels which emphasized the oceanic nature of fishing in Kamchatka. In 1966-1970, the volume of capital centralized investment amounted to 302 million rubles, in 1971 - 1975 - 342 million rubles, in 1985 - 445.7 million rubles. [9, F. 5. Op. 41. D. 151. P. 10; 12, F. 17. Op. 145. D. 426. P. 4]. Fleet modernization not limited by the remoteness of the navigation areas and climatic conditions, had a positive effetc on the extraction and processing of fish raw materials in a mechanized way [Figure 2].
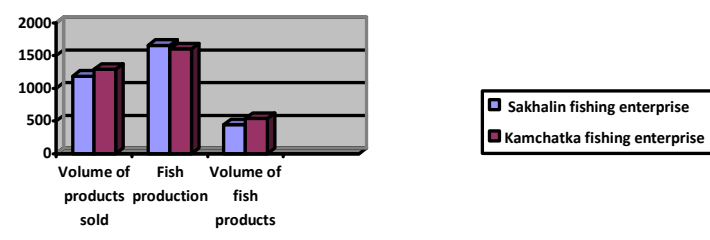

Figure 2. Performance indicators for the fishing enterprises of Sakhalin and Kamchatka regions in 1966 - 1970 (million rubles; thousand tons) [13, F.P-68. Op. 54. D. 203. P. 112].

The technical modernization was more complicated in Magadan region, where until 1969 the fishing industry did not have its own floating facilities. With the support of the local party leadership, Magadanrybtrest received 48 vessels, and until 1985 this number did not change. The problem of an acute shortage of vessels worsened because of oceanic fishing. The existing vessels were not able to cope with the volume of fish processing and supplied raw materials to the coastal enterprises of Magadanrybtrest, many of which became unprofitable. Their number was rapidly decreasing [12, F. 17. Op. 103. D. 601. P. 44; 9, F. 5. Op. 43. D. 118. P. 5].

Against this background, the capacity for repair and maintenance of vessels increased slowly, which led to an increase in imbalances in the dynamics of development of the fishing industry. During the period under review, the financial deficit of ship repair has constantly increased [Figure 3].

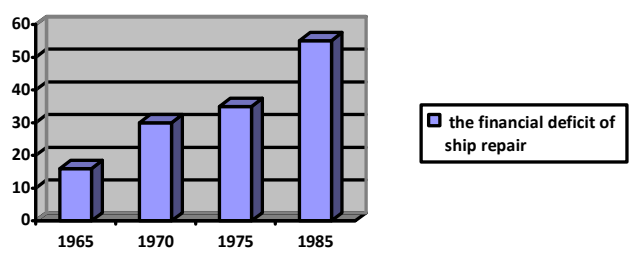

Figure 3. Dynamics of the financial deficit of ship repair in 1965 - 1985 (million rubles) [6, F. 399. Op. 3. V. 2. D. 726. P. 7].

Far Eastern ship repair enterprises did not use their capacities rationally, working in one shift. They had a lot of unidentified equipment; auxiliary operations were mechanized by $40-50 \%$, and there were no qualified personnel. Quite often, the intensification of industrial processes was replaced by slogans and all sorts of workers "initiatives" initiated from above, which resulted in emergency work. About 52\% of the vessels were out of repair in the third decade of the month. Whole-day and intra-shift downtime, loss of working time were significant.

For example, in the 1970s at the shipyards of Kamchatka region the cost of equipment stored in the warehouses amounted to 3003 thousand rubles, more than $40 \%$ of machines and mechanisms were used for 20 or more years. The replacement of obsolete equipment began only in the early 1980s. The ship repair base of Sakhalinrybprom did not have the technical capabilities 
(components, mechanisms, equipment) to provide the mining, processing and transport fleet in a timely manner, so more than $60 \%$ of the preventive repair of the BMRT was carried out outside the Sakhalin region, thereby significantly increasing its cost $[12$, F. 17. Op. 150. D. 465. P. 127].

The poor material and technical base of enterprises hindered the possibilities of accelerated, mobile repair of ships, which led to an increase in downtime. In 1975, the Kamchatrybprom vessels were at sea for $33 \%$ of the fishing time, while the target was 43\%; in 1985 - 9 thousand ship days and $13 \%$, respectively; the vessels of Sakhalinrybprom were at sea for 32 thousand ship days (46\%) [12, F. 17. Op. 154. D. 525. P. 19]

With the growth of crisis phenomena in the economy by the mid-1980s, the workers felt the lack of technical means for sorting fish and processing raw materials; therefore, fishermen were often forced to dump part of the catch overboard. Most fishing and processing vessels remained unprofitable. This caused accidents. For example, in 1971-1975, 114 accidents occurred in the Kamchatrybprom fleet with a damage amount of 13.5 million rubles; in 1976-1980, 157 accidents occurred with a damage amount of 4824.6 thousand rubles; in 1981-1985, 134 accidents occurred with a damage amount of 1115.9 thousand rubles. A high rate of accidents was observed in the Sakhalinrybprom fleet, where in 1980-1985 20 shipwrecks and accidents were registered, technical losses amounted to 137.8 thousand rubles; in Magadanrybprom, these figures were 7 and 48.2 thousand rubles, respectively [12, F. 17 . Op. 145. D. 424. P. 14].

In general, by the mid-1970s, a period of stabilization began in the fishing industry. The total number of industrial enterprises was more than 200 , including large seaports, shipyards, and the fleet. Fish was peocessed by 47 enterprises located along the Far East coast. The fishing industry included 4 fish processing plants and 1 fish factory in Magadan region; 12 fish factories in Kamchatka; 9 fish processing plants, 2 fish and 1 agar factories on Sakhalin; 2 fish processing plants and 3 fish factories in Khabarovsk and 11 fish processing plants and 1 agar plant in the Primorsky region [5].

Nevertheless, the economic situation in the second half of the 1980s was complicated by difficulties caused by the introduction of 200-mile economic zones the consequences of which were serious restrictions on fishing activities and significant changes in fishing areas. For this reason, fishermen of Kamchatka region did not add 62.5 million rubles to the gross output (94.8\%), in Magadan region, this figures were 5.3 million rubles or $89.4 \%$, respectively. In fact, in all the fishing regions of the Soviet Far East, many fish processing enterprises and floating canneries were idle due to the lack of raw materials. The fishing industry, its material and technical base, infrastructure needed time and money for restructuring and adapting consumers to new types of finished products.

As a result of the joint activities of the regional party and economic leaders of the Far Eastern territory, measures were taken to change the coastal fishing and processing base. For example, in connection with a significant reduction in the catch of coastal fish species, the coastal plants began to use raw materials from more remote areas (South and North Kurils). They processed new species of fish for canned food (saury, mackerel, etc.) and eliminated the factor of production seasonality [12, F. 17. Op. 150. D. 999. S. 8; 6, F. 399. Op. 3. V. 3. D.1435. P. 155].

\section{Conclusion}

The fishing industry of the northern regions of the Far Eastern territory developed in a national context, being an important component of the national economic system. State regulation of the industry was expressed in the formed vertical of management, the establishment of uniform purchase prices, centralized financing.Along with the reform, the centralized system of material and technical supply limited the economic independence of enterprises, negatively affecting their performance. At the same time, ministries continued to set economic indicators. In such conditions, the enteprises were not able to restructure the production process in accordance with the consumer market conditions and continued to supply raw materials in large volumes. The gaps between the growth rates of the capital-labor ratio of sectoral enterprises and labor productivity and between the dynamics of fixed assets and the total volume of output were gradually increasing.

The traditional fish-raw material base became depleted, new areas and fishing objects were being developed extremely slowly. Measures for fish conservation and fish farming were ineffective. The dynamics of modernization was influenced by the disproportions between the level of development of the coastal economy and needs of the fleet, the lagging of ship repair facilities, processing plants and industrial infrastructures. The material and technical base of the fishing industry of Kamchatka, Sakhalin, and Magadan regions needed special equipment that was not produced in the Far East, which aggravated the growing economic and economic crisis.

\section{References}

1. Yu. M. Kolesnik, Local history notes 4 42-49 (1973).

2. A.T. Mandrik, Pages of the history of the fishing industry of the Soviet Far East. Part 1 (1923 1958). (Vladivostok, 1974).

3. V.G. Svidersky, From the history of fishing in the Far East. (Vladivostok: RIO Primoruprpoligrafizdat, 1990).

4. A.T. Mandrik, The history of the fishing industry of the Russian Far East (1927 - 1940). (Vladivostok: Dalnauka, 2000).

5. N.M. Platonova Industrial and civil complex of the Far East of the RSFSR (1965 - 1985). The experience of historical development. (Moscow: Ethnosocium, 2013).

6. Russian State Archives of Economics (RSAE). 
7. P. Ya. Baklanov, Far Eastern region of Russia: problems and prerequisites for sustainable development. (Vladivostok: Dalnauka, 2001).

8. State Archives of Khabarovsk Region (SAKR).

9. Russian State Archives of Contemporary History (RSACH)

10. L.V. Volkov 2016 Institutional aspects of the development of the fishing industry of the Far East Regionalistics. 3 (6) 56 - 68 (2016).

11. State Archives of Sakhalin Region (SASR).

12. Russian State Archive of Social and Political History (RSASPH).

13. State Archive of Primorsky Region (SAPR). 